\title{
Téoros
}

Revue de recherche en tourisme

\section{Accessing the Canadian North and Arctic for Tourists-Past to Present}

\section{Jan Lundgren}

Volume 18, numéro 2, été 1999

La nordicité

URI : https://id.erudit.org/iderudit/1072115ar

DOI : https://doi.org/10.7202/1072115ar

Aller au sommaire du numéro

Éditeur(s)

Université du Québec à Montréal

ISSN

0712-8657 (imprimé)

1923-2705 (numérique)

Découvrir la revue

\section{Citer cet article}

Lundgren, J. (1999). Accessing the Canadian North and Arctic for Tourists-Past to Present. Téoros, 18(2), 44-51. https://doi.org/10.7202/1072115ar d'utilisation que vous pouvez consulter en ligne.

https://apropos.erudit.org/fr/usagers/politique-dutilisation/ 


\section{Accessing the Canadian North and Arctic for Tourists-Past to Present}

\section{Jan Lundgren}

The tourism phenomenon, in order to emerge and to be operational and workable, must establish a functional interaction between its three principal functional components: the travel-generating market, the transport mechanism, and the travel destination. As tourism inherently represents mobility of space, an effectively working transport function must be in place. Without such a function, no tourism! Tourism and travel history has demonstrated how the successive introduction of new modes of transport has rapidly trigge red increases of travel flows to destinations that, in an earlier era, had no such service, or perhaps only a rudimentary and insufficient transport link with travelgenerating (market) areas.

In accessing the Canadian North and Arctic with its vast and environmentally quite inhospitable environments, the improvement over time of the transport function has played a major role. This paper presents the process of improved transport access into the northern lands, especially the manner in which different modes of transport have been introduced. Perhaps the most outstanding innovation in terms of transport improvements was the launching of domestic passenger air services to northern lands, already in the early 20 's, departing from Winnipeg. Thirty years later, practically the whole east-west front of the Canadian Arctic could be reached by regular air transports operating from numerous southern metropoles, such as Montreal, Ottawa, Toronto, and Winnipeg. Paralleling the impressive growt of northern air services, other transport infrastructures have also contributed to an increase in popular northbound tourism travel: a number of railroad lines initially constructed for industrial purposes were also played a role in tourist travel development; in addition, the road network has also penetrated deeper into the North, starting with the Alaska Highway constructed during the World War II, and later complemented with other overland routes.

The past years have also seen a rapidly growing cruise ship trade focusing upon the Arctic archipelago north of the Labrador peninsula or the Pacific coastline, north of Vancouver toward Alaska. Thus, through multifaceted modes of modern and more convenient transport services introduced during this century, the Canadian North and Arctic lands are increasingly establishing themselves as exciting, adventurous and ACCESSIBLE tourist destinations for both domestic and foreign visitors.

\section{INTRODUCTION : FUNCTIONAL STRUCTURE OF THE TOURISM PHENOMENON}

The modern tourism phenomenon cannot function without its principal interactive components-an identifiable travel market, an appealing destination, and last but not least, an efficient transport linking function. These three elements produce the functional, operational, as well as spatial characteristics of the tourism mechanism: the Basic Tourism System (Lundgren/Hills,
1977; Leiper, 1979; Britton, 1980) They apply equally to historical as well as more modern eras of tourism travel. In a sense, the spatial manifestation inherent in the tourism travel construct outlined above constitutes the principal defining factor in the (tourist) production-consumption process, a process which differs fundamentally from the regular productionconsumption process for physical goods (Bittner, 1980).

In addition, the spatial factor matters in an inordinate way, both in the overall BTS construct, which links place of origin with tourist destination, but also on a more localized destination area scale level, where the tourist carves out his/her more restricted "operational" tourist space. Thus, (spatial) transport mobility, be it by fast jet plane services or on foot (walking) is a prerequisite to the full functioning of the tourism travel phenomenon. Without spatial mobility on both spatial scale levels: no tourism!

\section{GEOGRAPHIC REALITY DIMENSIONS-BRINGING THE FACTORS TOGETHER}

Looking at the tourism phenomenon in a Northern and Aretic Canadian context, the above is fairly obvious: the three factors Market/Transport/Destination shape the spatially extensive framework for Northbound tourism. The final impacting factor upon the Canadian tourism system, especially in a more Northern-Arctic context, relates heavily to the geographic dimensions of the Tourist Space as such. In contrast to more popular European or North American tourist destinations, the tourist space dimensions in the Canadian 
North and Arctic are nothing short of being very extensive.

The Canadian Northern tourist destination space cannot be seen in isolation, but must also be positioned in a wider, macro-geographic context. Hamelin's (1999) tantalizing delimitation of the circumpolar character of "The Northern World and Political Mega Regions" makes us realize both the vastness of the Northern Circumpolar World and its obvious diversity in spite of its high latitude boreal and arctic character. Equally interesting is the extent to which tourism already has established itself in some of the sub-regions. Thus, although the "Northern World" extends over a major portion of land and frozen seas around the North Pole, certain regional sectors, with less extreme climatic conditions and better relative access, have already experienced an important tourist penetration since World War II, and, in some cases, even much earlier (Lundgren, 1987, 1995). In Canada, the Western region, the Praries, and the James Bay-Labrador regions have seen different forms of popular tourism emerge owing to improved overland transport infrastructures and, since 1950, to the introduction of long-haul air services (Grieg, 1977; Airmag, 1982; Aviation Québec, 1980). Similarly, Iceland (area number 3 ) has been promoting tourism since the 60 's with the skilful market positioning of Icelandic Airlines as an alternative transatlantic service (New York-Iceland, Scandinavia-Continental Europe). As a result, Iceland recorded over 200,000 arrivals in 1996 (World Tourism Statistical Yearbook, 1998). The Scandinavian North (area number 9)-stretching from North Cape and Finnish Lapland southward to approximately the latitude of Lillehammer, Norway-has experienced both a coastal tourism development through the Hurtigrutten maritime shipping service Bergen-Hammerfest (North Cape) and a very successful fjord-andmountain based tourist resort development dating back to the late 19th century (Lundgren, 1995). Finnish Lapland saw its first major-and beautifully Finnish modernresort hotel development project north of the Arctic Circle in 1938 (the Pallastunturi Resort), followed by a regional development that has blossomed to encompass most of the Lapland County, but with major concentrations at Saarisalka (Jarvinen, 1988) and along the Finnish/Swedish border North of Pallastunturi in post World War II decades, deep into the Middle North zone.

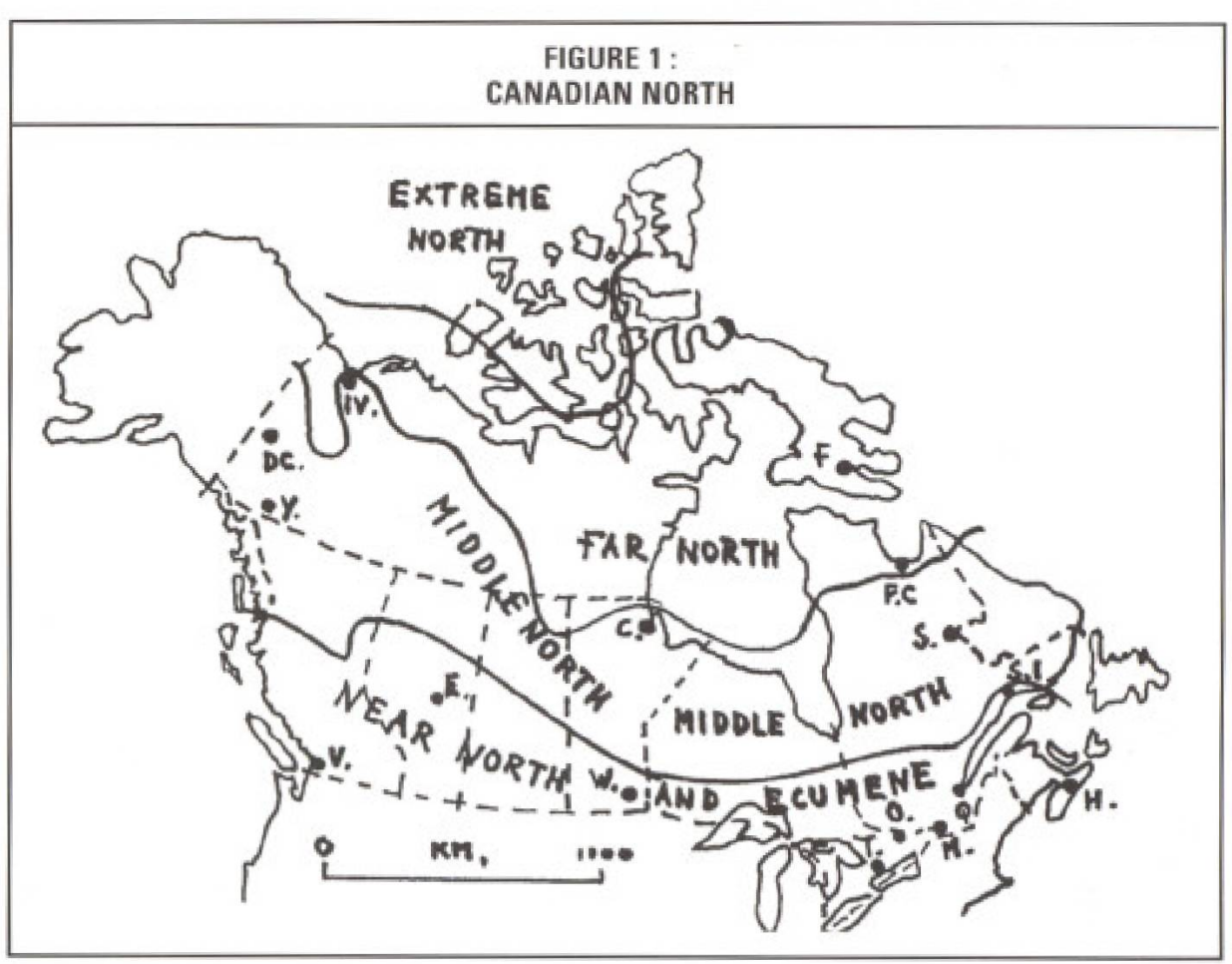

The diverse physical-geographic and environmental characteristics play a major role in shaping contemporary forms of Northern and Aretic travel, as they often site major tourist attractions. Still, when travelling to and within the Northern and Arctic regions, distances can be daunting. For example, the approximate overland straight-line distance to the Arctic shoreline from the principal East-West Canadian urban-metropolitan settlement corridor (see Fig.1 "Canadian North")-using Montreal, as the starting point-is $800 \mathrm{~km}$; the distance to the fabled Arctic archipelago in the Far North, North of the Labrador peninsula, again measured from Montreal, is almost 2,500 km-a long haul indeed! A similar exercise, applied to West Canadian conditions, using as point of departure Edmonton, whose latitude is much more northerly than Montreal and consequently some $900 \mathrm{~km}$ closer to the "true" North, fails to produce any substantial distance reduction: whether one strikes out straight North, or Northeast toward the Keewatin district, makes the distances only marginally shorter- $1,600 \mathrm{~km}$-a distance equivalent to Montreal-Savannah, Georgia or Paris-Messina, Sicily.

In the historical eras of northern travel, the travel time factor was critical. Regardless of mode of travel, plenty of time was always required to reach any chosen Northern destination. Even resorting to down- stream canoe-traveling on some of the fairly fast and easily traveled rivers such as the Mackenzie, the Nelson, the Moose, or the Abitibi did not substantially reduce the number of weeks required to travel westward the Arctic shores of the Beaufort Sea, or eastward to James Bay/Hudson Bay. Nowadays, the arduous overland and river-based travel has been replaced, in some cases, by either overland road travel to some Near North destinations or high speed air transportation-a blessing in its own right-but at a high price. In overall travel time terms, however, access to the North and the Arctic has improved greatly, particularly since the end of the $60 ' \mathrm{~s}$, when jet aircrafts gradually replaced propeller planes (Airmag, 1982). Still, the first air transport revolution affecting Northern access in the early 20 's was even more of a revolution!

Today we fly to geographically remote destinations such as Frobisher Bay, Pond Inlet, Resolute Bay, and Grise Fjord in a comfortable day's journey from the Canadian Ecumene with its principal travelgenerating metropolitan centers of Montreal, Toronto, Winnipeg or Edmonton. Alas, the cost is high for the average traveler. Therefore, in the world of popular tourist travel and destination choices, and in terms of transport costs, with equally "exotic" destinations elsewhere, the competition is fierce. For the price of an Arctic 
journey and ticket, or even less, the traveler-to-be can easily purchase an off-season overseas (package) ticket, which might take him/her to a different but nevertheless environmentally exotic destination offering an exciting contrast to "home", such as the Sahara desert in Morocco, or the Icelandic tundra landscapes on more northerly latitudes.

Given that price is a function of distance, a third and final factor that tends to damp down the northbound tourist penetration process can be identified: the rather unique, and limited market appeal for Northern tourism exposures in the typical North American or European travel markets. The identifiable market segment at present marketing prices can only be considered marginal, i.e. it attracts only a small percentage of the overall, high-season travel market. As a result, small northbound travel demand levels in themselves seem to be insufficient to effectively develop "scale economy" air fares for Arctic destinations.

\section{THE CONCEPT APPLICATION : SPATIAL PENETRATION}

The often sluggish and small volume nature of northbound tourism travel in Canada can of course be verified through the various exit surveys regularly administered at strategic points in the tourist travel system by local or regional tourist authorities. However, to understand the process by which different kinds of travel constraints over time has exerted a major influence on the travel movements, we must examine more closely the process behind the "opening up" of the North and Arctic to modern, contemporary forms of tourism. Particularly, we must understand how, over decades, the tourist frontier has gradually moved North and thus succeeded in conquering a greater portion of the spatially extensive and quite inhospitable Northern and Arctic spaces. This spatial penetration has been achieved against all odds, among which perhaps the lack of any settlements of substance has been the most strenuous obstacle, as the existence of a more comprehensive habitation and settlement system in the North, obviously, would have been of great (economic) use for participating transport logistics organizers and transport carriers. Therefore, the spatial transport penetration, and its inherent development dynamics, as it relates to the Canadian North and Arctic tourist space, is very much subordinated to some quite specific distance-related and spatio-geographic dimensions. In a sense, the "tyranny of distance" as described by Blainey for Australian development (Blainey, 1968) applies equally to Canada in general-and the North in particular. Still, for the Canadian North, only the early 20 's saw modern modes of air transport services introduced at strategically located starting points along the Northern edge of the east-west Canadian Ecumene (Provincial Archives of Manitoba; Lundgren, 1987).

\section{THE SPATIAL PENETRATION PROCESS}

To reconstruct the process of spatial transport penetration into the Canadian North we can benefit from some seminal works by historians and geographers. In broader continental-scale settlement development terms, the American historian Fredrick Jackson Turner's study of "The Signifi= cance of the Frontier in American History" (Turner, 1893) offers a persuasive, spatially dynamic, and "occupying" settlement diffusion interpretation of the US westward spread during the 18th and 19th centuries, which ultimately "closes" the frontier, i.e. brings about the transcontinental integration of the American geopolitical spacefrom coast to coast. However, Turner analyzed a westward oriented diffusion and penetration process with only a partial applicability to the Canadian westward version. Variations on Turner's theme, but with a more pronounced transatlantic backward linkage, was elaborated further by Vance in his Mercantile versus Centralplace Model (Vance, 1970).

Nevertheless, it is important to make the comparison with the westward Canadian transport penetration process, because of its relevance for any subsequent northbound transport development. The northbound thrust could only could be launched after the creation of a permanent and economic-geographically stable transcontinental East-West Canadian Ecumene, a project which got under way in the 1870 's through the Canadian Pacific Railway Corporation and was concluded in the mid $1880^{\prime}$ s. Only after the establishment of the national transcontinental rail service operation did the basis exist for a more contemporary northbound geopolitical and transport inspired expansion which, over time, would result both in a partial expansion of the settlement frontier into more marginal areas and the launching of a more systematic northbound transport penetration, which had a bearing upon tourist travel. However, as long as northbound transport access continued to rely upon overland or waterborne modes of transport. Canadian tourist travel was basically contained within the North American Ecumene. It was principally an interregional and intercity based travel phenomenon, its spatial extent more or less bound to the continental railway network. In contrast, northern tourism represented an expensive, gruesome, time-consuming and risky experience, attracting only a handful of adventurous travelers. However, with an East-West Ecumene corridor more effectively in place in the 1910 's and featuring a string of strategic urban centers, from Quebec City and Montreal in the East to Calgary and Edmonton in the West, the stage was set for launching northbound Canadian tourist travel in a geo-strategic manner that, in many respects, resembles the launching of the American westward settlement penetration but, admittedly, with constraints due to its northern and more inhospitable environment.

The truly spatial model conceptualization of the transport penetration process as such was developed by a trio of American transport geographers (Taffy, Morrill, Gould, 1963). Their study described a "colonial settlement process" in a part of the world with few if any similarities to the rather forbidding-and for six months of the year usually frigid Canadian North and Arctic-, the West African coasuline and more particularly today's Ghana and Nigeria.

\section{FROM WEST AFRICAN MODEL TO CANADIAN NORTHERN APPLICATION}

The Taffy-Gould-Morrill penetration development diagram (Fig. $2 \mathrm{~A}-\mathrm{B}$ ) presents a series of essential propositions highly relevant to the northbound Canadian equivalent. The following are worth mentioning: 1. an East-West linear principal maritime coastal access corridor - the result of a foreign-based waterborne transport function that establishes strategic foothold locations among a string of traditional shore-based village settlements; 2 . a deliberate concentration of economic, 
technological, and political "power" in a few strategic locations; and 3. a geopolitical and economic motivation serving as the main driving force behind the hinterland penetration. The West African coastal, colonial "linearity", combined with a "hinterland penetration", offers an inter= esting parallel to the CP-derived East-West railway corridor and subsequent Northern transport penetration efforts (Fig. 2A-B). Actually, the coastal and maritime linear' West African situation lays down the tactic" parameters of expanding territorial control deeper into the geographic hinterland along principal "penetration (trunk) line corridors" from which, at later stages, interconnecting traversing transport links are established. Over time, the whole interior hinterland space becomes integrated under the combined controlling economic, political, and colonial-administrative power base.

The geopolitical character of the West African penetration process obviously had its basis in overseas economic and colonial pursuits, that over the centuries had been by various European colonial powers. The development of the Canadian Ecumene can also be framed in imperial and colonial terms: through the establishment of the transcontinental Canadian transport and settlement corridor, a gap in the global "imperial" transport system could be filled. Little did one realize that in the process of this design, the essential basis for a more contemporary national Canadian northbound transport penctration was also laid, to be launched a generation later-in the 20 s, the $30^{\prime} \mathrm{s}$, and later on.

However, the West African model cannot be applied completely to the Canadian situation. First of all, the West African situation was a function of a maritime longdistance colonial control with little colonial settlement support in situ; the hinterland penetration was therefore strictly colonialcommercial and geopolitical. In contrast, the Canadian penetration, although at some historical stage colonially derived, was principally a domestic and national business enterprise, launched after the Confederation in 1867, driven by local, regional, or Dominion government interestsbasically by residents of the Canadian Ecumene-, as well as by imperial geopolitical parties and financial interests. The contrast becomes even sharper if one compares the conditions for the northbound Canada-based penetration: the deeper into the Northern hinterland the penetration process takes the traveler, the more marginal the conditions become, not only for settlement in general, but for the biomass environment as such. Thus, the negative factors of the nordicity equation become more apparent: for example, the early/late frost frequency increases rapidly as one travels north; the taiga vegetation gives way to treeless; commercially useless tundra approximately on he Labrador iron ore mining district latitude, summers become distinctly shorter and winters longer-all factors marginalizing the settement potential in general, but that may also have a bearing upon the potential for northbound tourist travel. The distances and settlement factors become paramount: one basically enters vast tracts of uninhabited areas, where surviving the elements become a dangerous contest for the visitor. This marginalization typifies the Canadian North and has only a partial equivalent in the West African hinterland toward its most extreme northern zone, where savannah vegetation changes into steppe grasslands-and ultimately desert environments. Thus, the two landscape extremes, West African heat and Canadian Aretic cold, have similar negative effects upon the visitor appeal. Also, in the original (West African) transport penetration process, a variety of settlements and populated tracts of land were incorporated in the rapidly expanding and integrated transport access space, which makes for a better economic-geographic underpinning of the spatial process as a whole.

FIGURE 2 A-B:

ORIGINAL TRANSPORT PENETRATION MODEL (MODIFIED BY J.0. LUNDGREN)

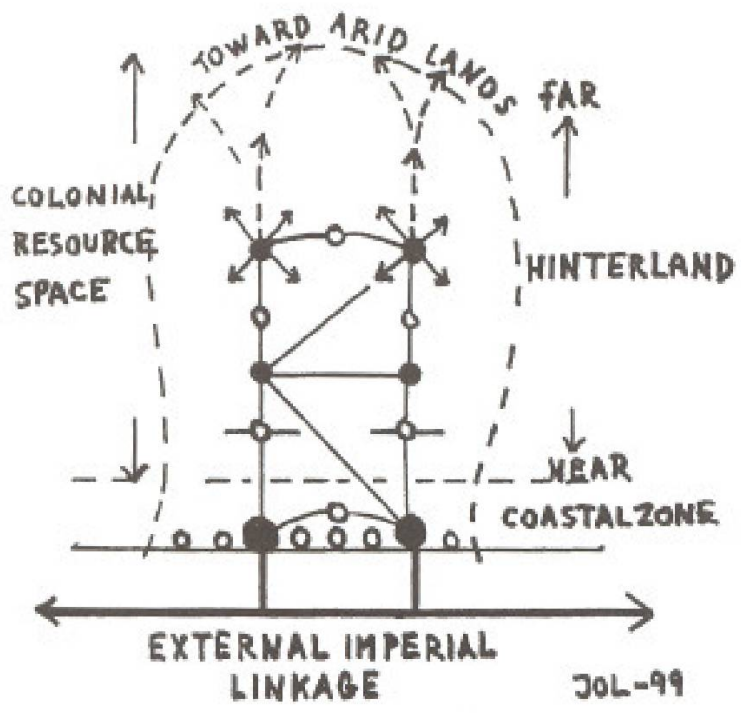

CANADIAN TRANSPORT PENETRATION SPACEE

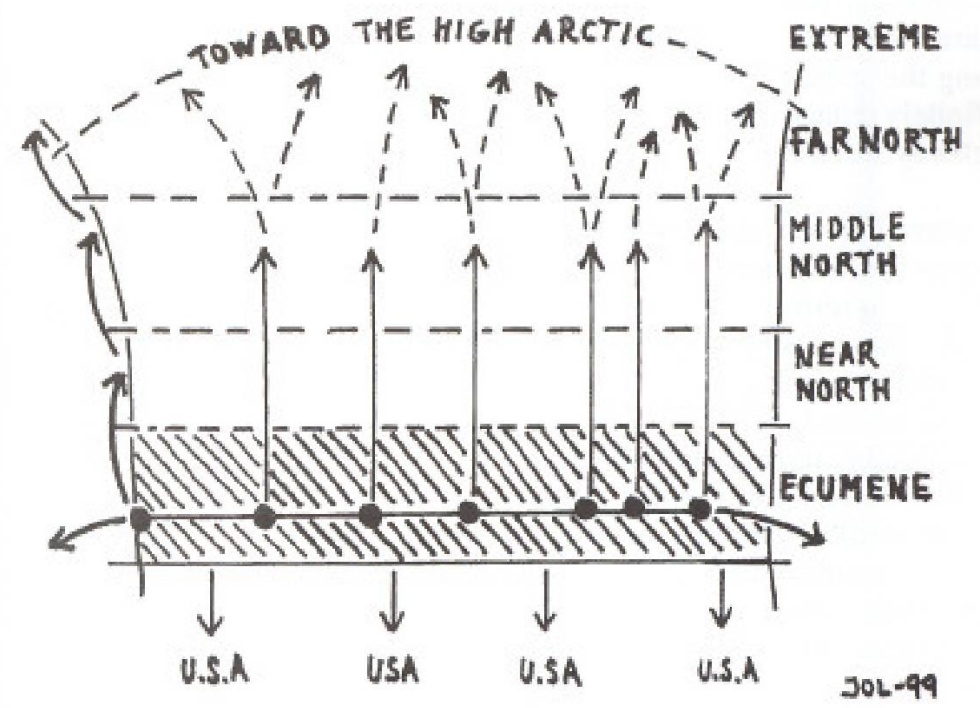




\section{THE REALITY IN ACCESSING THE CANADIAN NORTH}

The process of transport penetration of the Canadian North reflects a variety of factors, some of which have been referred to above. The following analysis will focus more specifically on the access characteristics of the different modes of transport that have been applied in more recent times-notably starting in the 20 's. The discussion will also relate to other factors that may have influenced the geographic characteristics of the transport penetration.

\section{OVERLAND ACCESS}

In terms of modern overland modes of transport, it is only during the World War II years and later that some major new developments have been witnessed (The Canadian Encyclopedia, 1984). In western Canada the strategically conceived Alaska Highway and, later, the "roads to resources" projects of the Dempster and Yellowknife Highways represented major long-haul transport infrastructure penetrations that struck deep into Alaska's Middle North zone, and literally reached the borderline of the Far North around the Great Slave Lake area (Fig. 1). All three resulted in an increase in both commercial traffic and individual tourist car travel. However, the growth in car-based tourist traffic must not be exaggerated: the excessive approach distances from the Canadian Ecumene mitigated actually against any massive recreational and touristic car travel invasion-the long travel time and the high return travel cost, unless the tourist returns along the same route as he drove North, definitely reduce the tourist utility of these highway infrastructures.

In central Canada, and further East, Northern road penetrations have been less impressive in terms of distances, and have equally never been a product of tourist market demand. Rather, other interests lie behind the road network expansion northward, notably resource industry and public utility interests (Warkentin, 1968). The tourists usually come later, literally "piggybacking" on the already constructed transport infrastructures. In northern Manitoba mining industry, interests were behind the push for an extension of the central road system northward to The Pas, Flin Flon, Thompson, and Lynn Lake all the way to
Uranium City. In Ontario, the "road to the Arctic" materialized rather in the form of a railroad to Moosonee (Ontario Northland Transport Commission, 1986), opened in 1931 than a highway. In fact, with few exceptions, the Northern limit of the provincial road system barely reached the latitude of Lake Abitibi, some $250 \mathrm{~km}$ south of the James Bay shoreline.

In Quebec, the "Power from the North" policy introduced by the Bourassa provincial government and Hydro-Quebec in the early 70 's saw a decisive extension of the road system from Chibougameau, and the Abitibi mining region became part of the James Bay hydro development project. Thus, major government strategies carried the road north to L.G.2/Radisson, and East past the string of impressive hydro dams all the way to the Caniapiscau reservoir "only a stone's throw"-some $200 \mathrm{~km}$-from the Scheffferville mining area. In addition, the opening of the James Bay area to (public) road traffic has produced a substantial increase in car-based tourist travel in spite of the arduous return journey along the same route. Still the marketing concept of a St. Lawrence Gulf to James Bay Northern trip can now be activated, with the starting point at Tadoussac, at the mouth of the Saguenay Fjord, and the journey's end being the comfortable hotel service in "downtown" Radisson. Alternatively, tourists can travel northward on Route 117 from Montreal to Val d'Or and via Matagami reach the same James Bay destination. The eastbound highway along the Quebec Northshore, East of SeptÎles (Côte-Nord Tourist Guide, 1997), must not be underestimated from a touristic point of view. With the establishment in 1984 of the Mingan National Park-26,000 visitors in 1996 (Canadian Global Almanac, 1996)-and the coastal ferry connection toward Blanc Sablon and Red Bay further east, a magnificent experience awaits the car traveler. However, to make a convenient tourist travel loop via Newfoundland's Great Northern Pensinsula increases the homebound travel costs and time excessively-and the route is hardly "northbound"! Existing maritime transport services northward, however, along the Labrador East coast, can bring tourists all the way to Nain and even further, but again at considerable costs and fairly long travel time!

On the whole, it can be argued that from a tourist travel point of view, the car jour- ney North toward a number of end-of-theroad/cul-de-sac destinations only has a limited market appeal, hence the dominant utility of these long-haul transport arteries will remain industrial in the foreseeable future.

\section{THE RAILWAYS}

The Canadian northbound railway penetration has also contributed to Northern tourism development. Admittedly, its role has been modest compared with, for instance, that of the national railway systems in other northern countries such as Sweden and Finland, where railroads (Lundgren, 1995) into Northern mountain zones both in Northern Sweden and Finnish Lapland successfully linked into untapped tourist resources as much as industrial resources (Swedish Lapland versus the Kiruna iron ore fields or frontier-based colonization settlements in Finnish Lapland). Thus, passenger bulk transport economics were achieved from the beginning of the tourist development. The Lulea-Narvik Lapland railway line, opened in 1904, is a case in point. This line and other northern lines indirectly mobilized potentially large travel markets which, in turn, justified numer= ous rustic resort facility projects in the fjell mountain zone, most conveniently accessible by rail.

The railway penetration into the Canadian North and Aretic did not link up with landscape features of a comparable touristic appeal. Although the Winnipeg-Port Churchill Railway opened in 1929 (Canadian Encyclopedia, 1984), the Depression Era also hampered its tourist usage in spite of the obvious advantage for tourist passengers on the Hudson Bay Company's supply ship S.S. Nascopie arriving at Port Churchill, to transfer to trains for their final return journey south to Winnipeg-or vice versa (Hudson Bay Company Archives). The Hudson Bay railway had, potentially, a strategic role to play for Arctic tourism but its impact was nevertheless minor: for the years of S.S. Nascopie passenger list recordings (1932-37) only small numbers of tourists were recorded. And then came World War II. The subsequent rail link north to Lynn Lake in Manitoba has an obvious tourist utility because it takes the traveler into an extensive section of the upper tributaries of the Churchill River, an environment ideal for sport fishing. 
Still, even by rail, the distances make for a time-consuming "approach journey", which may not suit the modern tourist's impatient personality!

The second "Arctic" railroad-the OntarioNorthland Railiroad-popularly marketed as the "Polar Bear Express" fared considerably better. Opened in 1931 , little was achieved during the remainder of the 30 's due to the Depression. Ultimately, the line connected Cochrane in the Northern Ontario mining region straddling the eastwest Canadian National rail line with Moosonee at the southem tip of James Bay opposite the historic Hudson Bay $\mathrm{Co}$. trading post at Moose Factory (Ontario Northland Transport Commission information). Thus, the railway service provided the travelling public-for the very first time-a reasonably convenient access to the Arctic shore and to a famous historic site as well. However, it is doubtful that the Ontario government was guided by tourist travel market surveys when planning the railway link. Rather the riches on/in the ground, the opening of a potentially new mining resource frontier as well as an urge to "integrate spatially" the northernmost parts of the "provincial empire" were probably the driving force behind the railway project. Nevertheless, after World War II tourists flocked to this new, adventurous travel experience, which suggests that the ticket pricing was reasonable. Thus, over the years, tens of thousands of travelers annually exploited the opportunity to "take the train to the Arctic", Although the economics of the railway always was a matter of public debate, annual passenger volumes grew from 46,000 in 1968 to 72,000 in 1980 , of which approximately $60 \%$ were excursionists. Presently, for 1998 , the tourist passenger flow has amounted between 15,000 and 20,000 excursion travelers annually during a short six-week summer season operation (from June 25 to Labor Day weekend in the early September) and demand has remained steady over the past four years (Ontario Northland Transportation Commission, 1998). If "roads to the North" later were slow to bring in tourists, the Polar Bear Express was the first to be truly successful in this regard.

The third rail penetration, the Quebec North Shore and Labrador Railway equally relied on industrial resource economics. The line was part of the massive mining investment undertaken in Central Labrador after World War II, a resource investment which could not have been activated without a proper iron ore fields railway linking major mining operations at Knob Lake. Quebec (later renamed Schefferville) and Wabush Lake, Newfoundland-Labrador (later named Fermont, Wabush, and Labrador City) with the Sept-Îles port town some $500 \mathrm{~km}$ to the south. Over the years, the line did carry a considerable inter-local passenger traffic volume, but only a smaller portion were true tourists (Q.N.S. and Labrador Railway Company, 1979). Still, in the most recent year for which this author has a recording, some 43,000 persons used the train. With the closing of the IOC Schefferville operation traffic has obviously dropped. Prior to the Hydro development at Manicouagan and the establishment of the mining city of Gagnon slightly further north of the Hydro reservoir, the railroad was the provider of inexpensive access to sport fishermen, hunters, and wilderness adventure tourists into the Central Middle North environment.

The fourth and final northern railroad line developed in conjunction with the Manicouagan Hydro scheme and the subsequent urban development of the City of Gagnon some $300 \mathrm{~km}$ northwest of the port terminal at Port-Cartier (Warkentin, 1968). In a sense, the tourist attraction in this area rests with the Manicouagan Reservoir and power facilities, officially opened in 1968. a project which in many respects represents the overture to the James Bay developments of the 70 's. Access is much better and, in terms of nordicity, the tourist is practically on the same northern latitude as Moosonee, on the shores of James Bay.

\section{NORTHERN AIR SERVICES}

Whether by road or rail penetration, the North and the Arctic posed major access problems for tourist traveling until the advent of air services. Embarking and disembarking from wide-bodied passenger jets in today's comfort, it is hard to imagine the "transport revolution" of the $20^{5} \mathrm{~s}$, when the first air services specifically geared for Northern destinations were introduced (Statistics Canada, 1971). The speed differential and travel time reduction com= pared with traditional modes of transport were on a scale hard to appreciate in today's global access situation. However, compared to canoe traveling, even the earliest rather rickety passenger air services represented a transport revolution of highest order. And it had an absolutely perfect "fit" with the lay of the land as described at the time. As it was very poignantly put: "... the main impetus for commercial flying was the lure of the vast trackless North rich in minerals and forest resources... (and) denied regular transport links" (Statistics Canada, 1971).

Surprisingly, the air service penetration of the North did not begin in the East where society perhaps viewed access from a Canadian Ecumene perspective and therefore took a rather dim view of arguing for improved access toward economically marginal travel destinations. Further West, things were viewed differently. Thus, the very first regular northern passenger flights took place in Manitoba, in 1920, between Winnipeg and The Pas, when an $800 \mathrm{~km}$ trip was covered in two days-an unbelievable record by the transport standards of the time. The free wheeling 20 's saw the establishment of a host of more or less reputable air passenger operations based in Winnipeg (Statistics Canada, 1971). among which figures the fore runners of regular, modern Canadian airlines of fu= ture years, such as Air Canada and Canadian Airlines: in 1925 the Richardson family of Winnipeg launched the Western Canadian Airways-the original fore-runner to the 1937 Trans Canada Airlines Corporation and today's Air Canada (Fig. 3). Four years later, "Western" was renamed Canadian Airways and had already developed an extensive network that stretched from Hudson Bay with Port Churchill near the Middle North zone to the city of Fargo, upstream from Winnipeg, in North Dakota, US. The company serviced emerging-and remote-urban centers such as The Pas, Flin Flon and Stony Rapids, the latter not far from today's Uranium City. In the mid 30 's the network reached deep into the Far North zone on both sides of the Hudson Bay, with access points at Baker Lake/ Chesterfield Inlet over $500 \mathrm{~km}$ north of Churchill, and approximately on comparable latitudes on the Eastern shores of Hudson Bay (Fig. 4).

The Western Canada Airlines was not the only one, but it represented in a fairly typical manner the vigor of the Winnipegbased airlines in those days. Its regional competitor for instance, Arrow Airways, equally ran a wide ranging operation but with a stronger Northern focus, as its mid 

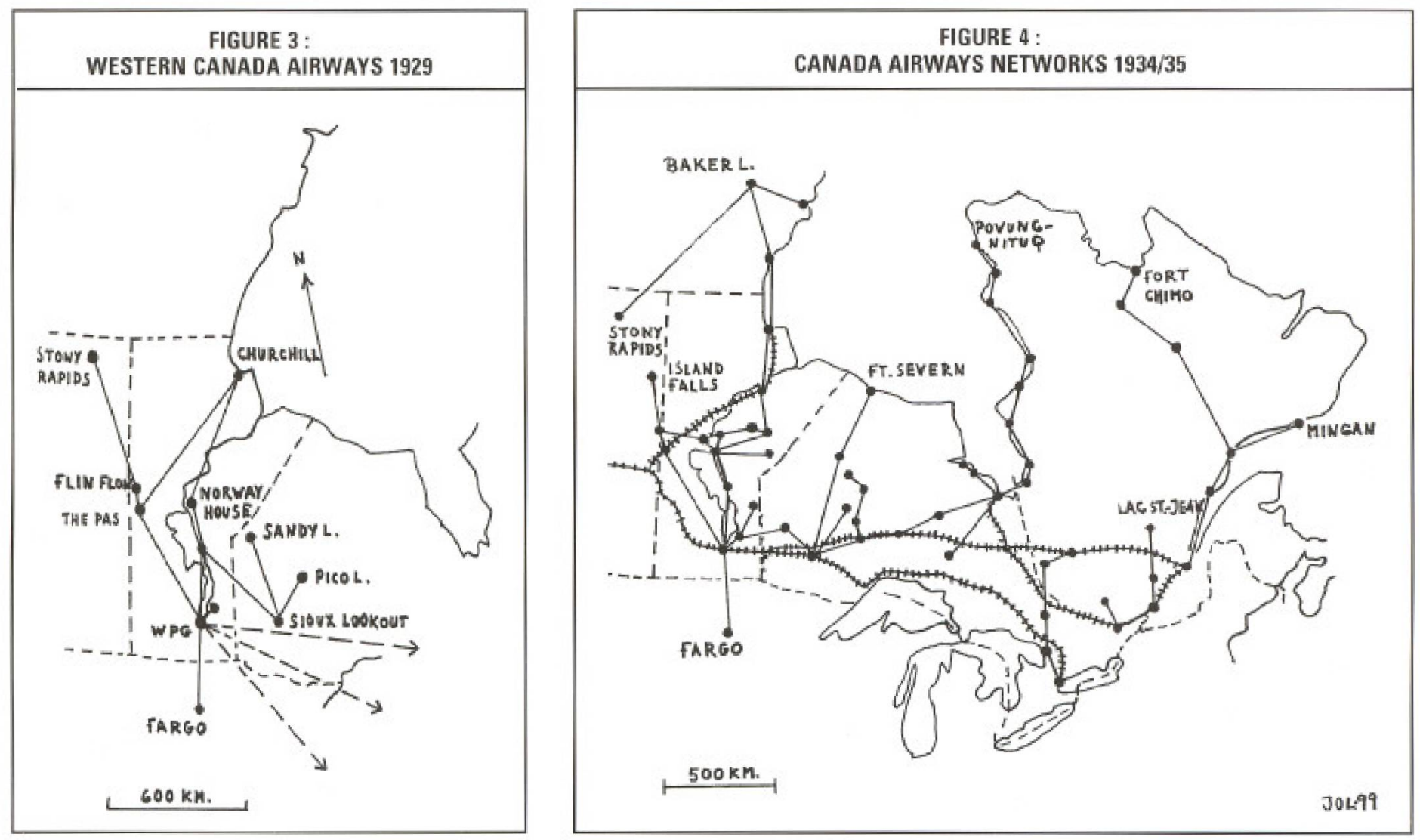

30 's network suggested. Needless to say, the economic geography frontier was pushed North-and the tourists followed suit especially after a few years, when the safety record of the air services seemed to be satisfactory.

A similar successful airline enterprise was responsible for the opening up of the Labrador peninsula and the Far North to the east of Hudson Bay. Here, Boreal Airways started operations from SaintFelicien at Lac-Saint-Jean (Airmag, Supplement, 1982). In a few years' time Boreal's network had expanded beyond the region to include services to Fort Chimo, Poste-de-1a-Baleaine. Came the 50's, and the whole of the Labrador peninsula was within effective reach both through regular services and a large number of bush pilot services-former prospecting party pilots now discovering a new market-the sport fishermen and sport hunters (Lundgren, 1982). The invasion throughout the Labrador peninsula of outfitter enterprises (CôteNord Tourist Guide, 1997; Tourisme Québec, Map of "Quebec's Far North", 1995) has partly its origin in the gradual decline in mining prospecting expeditions after the big iron ore discoveries in the late 40's (Lundgren, 1982).

\section{"CLOSING THE CANADIAN NORTH AND ARCTIC"}

The final stage of accessing the Canadian North and the Arctic in its full East-West width had an early start, as can be seen from the account of the early air services into Northern areas initiated in the 20's. Clearly, both courage and economic vision as regard rich Northern resources played an important role in this endeavor.

In the final stage of northward penetration, the growth of air services continued to be the principal actor. The growth of Nordair (Boreal Airways) during this period can serve as an example of the development during the 1950-1980 period, which truly brought about the "closing" of the Canadian North and Arctic frontiers. Up until 1960 the company operated primarily within the Near and Middle North zones barely touching the so-called Far North zone at Ungava Bay, On the early 50 's the company had widened its network westward to incorporate the Abitibi mining towns into its service network, as well as smaller settlements on the Hudson Bay coast. However, the "big leap North" was made in 1962, when the first truly "Far North" Nordair flights were inaugurated:
Montreal-Frobisher Bay (Southern Baffin Island) -Resolute Bay (Cornwallis Island off the Northern tip of Baffin Island on lat. $\left.75^{\circ} \mathrm{N}\right)$, almost $1,500 \mathrm{~km}$ north of the Arctic Circle (Airmag, 1982). To go further did not make any sense, literally.

A major factor behind Nordair's northern involvement stems from other Northern and Arctic activities pursued by the Federal Government during these decades. With the Cold War taking a turn for the worse in 1950, when the Korean War started, as well as other major but related intemational political events and confrontations in other parts of world, US-Canada agreements about joint defence plans for the North came into effect, resulting in the construction of the early warning radar systems running east-west across the continent on northern latitudes (Lafay, 1958). The construction program required massive government funding for installation projects in the North, including provisions for transport infrastructure, especially in the form of air landing strip facilities in order to effectively service the construction program. Consequently, the demand for air-supplied provisions and construction material increased rapidly and remained constant for a number of years. Nordair, 
then operating out of Montreal and Ottawa, benefited greatly from this strategic construction program, as the airline did later, in the 70's, during the James Bay Hydro Development program. Thus, the sustaining force in a kind of final "closing of Canada's Northern Frontier" was neither a tourism derived nor an industrial resource derived development, but a result of global geopolitics, North American political security concerns (Lafay, 1958) and provincial industrial strategies. It is indeed ironic that, ultimately, military policy strategies seem to have laid the transport groundwork from which peaceful tourism travel could benefit, but nevertheless this certainly seems to have been the case.

The extent of the contemporary air access situation for Northern and Arctic destinations can be gleaned from Grieg's 1977 study of the Canadian regional/northern network. Although dated, this study and the Aviation Quebec Report (1980) nevertheless identifies the three principal Northern access corridors that today carry travelers into the High Arctic with appropriate stops en route: in the East, the Quebec-Labrador-Baffin Island corridor, with a very dense system in its lower part, up to Kuujuaq at Ungava Bay; in Central Canada, Winnipeg has retained its historically developed pioneer air service position for northbound services which, via Port Churchill, take the traveler to the High Arctic archipelago slightly West of Baffin Island; and, in the West, Edmonton/ Calgary performe a comparable channeling role, while servicing both Inuvik in the Mackenzie Delta area further to the West as well as Victoria Island (Cambridge Bay) west of Baffin Island. The east-west connections were weakly developed in the mid-70's, although they did exist on very high latitudes over the skies of Baffin Island, or on the latitude of Port Churchill. Still, the extensive Hudson Bay was not crossed by any regular airline services at that time. Today this situation has most likely changed.

\section{SUMMARY}

The rest of the northbound transport penetration is history! Its real and final thrust occurred in the 70's with the various airlines serving the North and the Arctic shedding their traditional aircraft fleets, replacing them with jet plane services. To access the Arctic-which had been both a time-consuming and laborious exercise throughout centuries-for explorers, merchants, and pleasure travelers alike, is now an easy enterprise, where the only principal obstacle seems to rest with "price" and the specific nature of the destination area experience. The access "price" is a variable factor, which in the future can be modified either by the "right" changes in market forces or by changes in Northern tourist policies. Thus, the real problem for a dynamic Northern and Arctic tourism development may very well rest with the type of tourist experience this very specific destination area can offer. After all, it is very hard to alter the intrinsic geography of a place! But new factors have recently established themselves in the Northern regions: the emergence of new geopolitical configurations, such as Nunavut, will definitely influence future tourism strategies-how and in what directions remain to be seen.

\section{BIBLIOGRAPHY}

Airmag via Nordair (1982), Nordair's 35 years. Supplement, II, 7, Montréal.

Bittner, M.J. and B.H. Booms (1980), "New Management Tools for the Successful Tourism Manager", Annals of Tourism Reseanch, VII, 3 . p. $337-352$.

Blainey, F. (1968), The Tyranny of Distance.

Britton, S.G. (1980), "A Conceptual Model of Tourism in a Peripheral Economy", in D.G. Pearce (Ed.), Tourism in the South Pacific: The Contribution of Research to Development Planning. p. 1-12, MAB Report No. 6, N.Z. National Commission for UNESCO. Geography Dept. University of Canterbury, Christchurch, N.Z.

Canadian Encyclopedia (The) (1984), on "transportation" and place names.

Canadian Global Almanac (The) (1996), MacMillan, Toronto.

Grieg. J.A. (1977), Erude des rransporteurs régionaux, Ottawa.

Hamelin, L.E. (1999), The Northern World and its Mega Regions, presentation at the Congrès Mondial sur la Nordicité, Quebec City.

Jarvinen, Juoko (1988), Turismutveckling en Studie ar Foretagsledningens Perspektiv (Tourism Development from the Tourist Service Enterprise Perspective), 010, Licentiatuppsats, Institutionen for Industriell Ekonomi, Lulea University, Sweden, 153 p.

Lafay, F, (1958), "DEW Line", National Geographic Magazine, 114, juillet-décembre, p. $128-146$
Leiper, N. (1979), "The Framework of Tourism: Toward a Definition of Tourism, Tourist and the Tourist Industry", Annals of Tourism Research. VI, 4, octobre-décembre, p. 390-408 (See esp. Fig. 2 "The Tourism System"').

Lundgren, J. et T. Hills (1977), "The Impact of Tourism in the Caribbean: A Methodological Study", Annals of Tourism Research, IV, 4, mai, p. 248-267.

Lundgren, J. (1982), "The Tourism Frontier of Nouveau Québec: Functions and Regional Linkages", Revue de Tourisme, 2, p. 10-16.

Lundgren, J. (1987), "Tourism Development in the Northern Periphery", Teoros, 6, 1, mars, p. 13-19.

Lundgren, J. (1995), "The Tourism Space Penetration Processes in Northern Canada and Scandinavia: A Comparison", in C.M. Hall and Margaret Johnston (Ed.), Polar Tourism - Tourism in Arctic Regions, Wiley Publishers.

Mieczkowski, Z.T. (1974), "Developing Tourism in the North", in F. Helleiner (Ed.), Proceedings of a meeting of the IGU Working Group of the Geography of Tourism, Trent University. Dept. of Geography.

Ontario Northland Transportation Commission / Head Offices (1998), Information on Polar Bear Express Railway Passenger Staristics and the 1998 Polar Bear Express Information Book. let, North Bay, Ontario.

Provincial Archives of Manitoba, Richardson Family files (Airline route maps).

Quebec North Shore and Labrador Railway (1979), Sept-Îles, information on Railway Passenger Statistics.

Statistics Canada (1971), Aviation in Canada, Cat, Occasional Statistics Canada. No. 51-501 (See esp. "Genealogy Chart for Regular Air Carrier 1920-1970").

Taffy, E.J., R.L. Morrill, et P. Gould (1963), "Transport Expansion in Underdeveloped Countries", Geographical Review, octobre, p. 503509 (See esp. "Diagram discussion" p. 503-513).

Tourisme Québec, (1997), Côte-Nord Tourist Guide.

Turner, FJ. (1893), "The Significance of the Frontier in American History", American History Association, Reprint.

Vance, J.E., Jr. (1970), The Merchant's World: The Geography of Wholesaling, Englewood Cliffs, N.J.

Warkentin, J. (Ed.) (1968). Canada - A Geographical lnterpretation, University of Toronto Press, Toronto.

W.T.O. (1998), World Tourism Statistical Yearbook, Madrid, Spain. 